\title{
The Effects of Performance Appraisal on Lecturers' Productivity: Evidence from Koforidua Polytechnic
}

\author{
Addy Elizabeth ${ }^{1}$, Dzisi Smile ${ }^{2}$ \\ ${ }_{1}^{1}$ Quality Assurance Directorate, Koforidua Polytechnic, P.O.Box KF 981, Koforidua, Ghana \\ Email:kukuaddy@yahoo.com \\ ${ }^{2}$ Department of Purchasing and Supply, Koforidua Polytechnic, P.O.BoxKF 981, Koforidua, Ghana \\ Email:afuasmile@yahoo.com
}

\begin{abstract}
The significance of performance appraisal as a major and pivotal human resource activity required for the growth, development and success of any organization can hardly be overemphasized. Unfortunately, in most public sector organizations, this fundamental activity is not given due importance. The ultimate corollary of this scenario appears in the shape of slow progress and lower productivity of the employees and of the organization as a whole. It is therefore important for organizations to have a performance improvement plan as a guide to where we are now, wherewe want to be and how we will get there. The study looks at the performance appraisal process, compliance by lecturers and its effects on lecturer productivity at Koforidua Polytechnic. . Data was obtained from staff (79) and students (470) of Koforidua Polytechnic usingstratified sampling technique. The study revealed that the performance appraisal process in Koforidua Polytechnic is closely linked to sound policies that conform to standards.The study indicated that performance appraisals have not improved lecturer's productivity from the perspective of students which is in contrast with appraisal reports generated from2006 to 2010. The resolution to this controversy lies in providing adequate feedback to students as management takes action on students' concerns. This paper also revealed the extent to which performance appraisal by students has affected lecturer's productivity with analysis onits importance to the polytechnic, strengths and weaknesses and as well provided improvement measures.
\end{abstract}

Keywords: Performance appraisal; Productivity; Employee; Effectiveness; Organization.

\section{Introduction}

Decisions made about the value of an institution are often based on its productivity (Reingold and Stepanek, 2000). According to Mathis (2004), the more productive an institution is, the better its competitive advantage, because the cost to produce its goods or services is lower.Shresta (2005) commented that organizational productivity has the major aim of bringing about lasting improvements in performance.Staff productivity will require that institutions put in place adequate motivational strategies and economic incentives (Ologunde et al., 2007).Performance appraisal of staff is carried annually or bi-annually as a tool to promote and sustain productivity in organizations. It is important that members of the organization know exactly what is expected of them, and the yardsticks by which their performance and results will be measured (Terry and Franklin, 2003). Administrative uses of performance appraisal are often the link between rewards employees hope to receive and their productivity. The linkage can be thought of as follows:

Productivity $\longrightarrow$ Perfomance Appraisals $\longrightarrow$ Reward

Developmentally, performance appraisal can be a source of information and feedback for employees, identifies strengths and weaknesses, recognizes performance and is a key to future growth and improvement in productivity (Mathis and Jackson, 2004).

Performance appraisal provides a pathway to quality teaching in tertiary institutions; as targets or objectives set are accomplished by teachers in order to improve performance that meet the institution's expectation. Management are able to take proactive decisions on the institution's performance with regards to teaching, learning and research.

The Polytechnic introduced performance appraisal for teaching staff in 2006/2007 and was implemented by the Planning Department. The main challenge is the 
low level of compliance to some of the indicators as provision of the course outline, mode of delivery, lecturer's bearing in class and pedagogy. Students do not have much understanding in assessing the teaching staff objectively on their teaching performance. There is inadequate education and sensitization for students on how well to evaluate and rate lecturers' performance. A key shortfall is the inaction on feedbacks, inappropriate interviews and poor usage of appraisal results. Commitment of Management to enforce compliance to standards on performance appraisal and provide the needed resources and training for effective appraisal system is inadequate. The need to evaluate performance appraisal process from2006 to 2010 and its effect on lecturers' productivity is of paramount importance to the institution's development as the Polytechnic continues to expand and grow. The challenges require further examination of performance appraisal process and its effects on lecturers' productivity as well as lecturers' compliance to standards on performance appraisal in Koforidua Polytechnic.

\section{Performance and productivity}

Performance appraisal is a process typically delivered annually by a supervisor to a subordinate designed to help employees understand their roles, objectives, expectations, and performance success. In the most basic sense, productivity is a measure of the quantity and quality of work done, considering most of the resources used (Mathis, 2004). It is simply a question of efficiency. In the academic context, productivity means effectiveness (Keirstead, 2010). Academic staff productivity is the efficiency with which the faculties or departments perform their multiple responsibility of
a)Learning (product of teaching), b) Knowledge and scholarship (the product of research and scholarly activities) and c) Institutional, community and professional well-being (the products of shared governance, community service and professional activities) (Kusure et al., 2006).

Measures of productivity in teaching are grouped into four: Course presentation, Mode of delivery, Lecturer's bearing in class and Pedagogy. Course presentation identifies the course title and objectives, course outline with references, lecture notes, course content and description by teaching staff. Mode of delivery addresses teaching staff's command over the subject, effective communication during teaching, use of appropriate teaching methods and class interaction. Lecturer's bearing in class examines punctuality, regularity, responsiveness to students' question and adequate class assignments. Pedagogy in this context looks at issues on timely submission of marked assignments and discussions in class, organization of examinations and teaching staff's appearance or demeanour). Each of these factors is indicated on the appraisal form, for which students assess lecturers, by using the five point scale ranging from 1-5. Stakeholders include Management, Lecturers, Students and Planning Department. As indicated in Fig. 1, the entire cycle begins with students' appraisal of teaching staff at the end of each semester. The graphic rating method of the trait approach is used to statistically analyze the data. The appraisal results are then communicated to lecturers and Management with the preparation of the appraisal document. The feedback is given to lecturers helps to identify the areas needed for development and is also used for administrative purpose, which will intend improve performance.

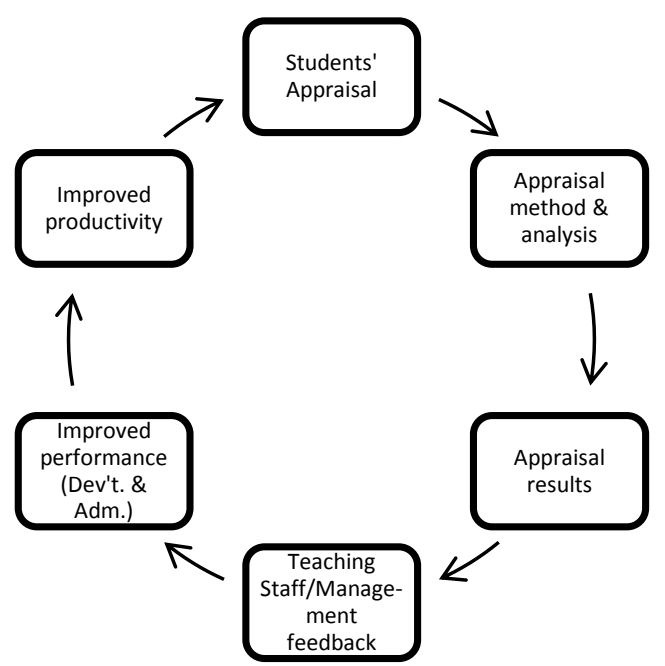

Fig. 1: Conceptual framework of performance appraisal process of teaching staff at Koforidua Polytechnic. 
According to Ivancevich (2004), there must be active communication between the supervisor and subordinate about performance. Formal performance appraisal programs sometimes yield disappointing results. Some of the most common problems include: inadequate preparation and training or giving feedback on the part of the supervisor and employees are not given clear objectives at the beginning of performance period. Supervisor may not be able to observe performance or have all the information. Furthermore, unclear performance standards and inconsistency occur during appraisal among supervisors, thereby rating personality rather than performance, subjective and vague language (Evres et.al, 2002).Carefully implemented performance appraisal process leads to sustainable growth of productivity, while poor and uncoordinated performance appraisals lead to poor feedback, and reward systems resulting in poor productivity (Beardwell and Holden, 1998). It is therefore of utmost importance that feedback from performance appraisal receives the needed attention for its sustainability and improvement in teaching and learning outcomes.

\section{Methodology}

Designing a research plan calls for decision on the research approaches, research instruments, sampling plan, data sources and contact methods (Kotler and Keller, 2006). A survey strategy was employed with target population being students and staff of Koforidua Polytechnic. The population for students and teaching staff of Koforidua Polytechnic was 4170 and 166 respectively as at 2011 (Students' Records \& Human Resource Department).

A sample size of 559 was used for the study for staff and students of Koforidua Polytechnic using random stratified sampling technique. Semi structured questionnaires were administered to Management (22), Planning staff (7), summing up to 79 for staff and 480 for students of Koforidua Polytechnic. Interviews were conducted for Management, teaching staff and the Planning Office. The factor analysis and the descriptive statistics were used to analyze the data collected for the performance appraisal process and its effects on lecturers' productivity.

\section{Discussion of results}

This section deals with selected responses to the objectives of the study as well as the various research questions presented to respondents.

Table 1 shows the breakdown of the population, sample size, survey responses and interviews according to their positions in the study. A total of three hundred and ninety three (393) out of five hundred and fifty nine (559), representing 70\%, questionnaires were collected from staff and students. This indicates a cross-section of staff and Students who took part in the study.

Table 1

Demographic characteristic of respondents

\begin{tabular}{lllll}
\hline Position / Rank & Population & Sample size & Survey Responses & Responses (\%) \\
\hline Management & 22 & 22 & 19 & 86 \\
Lecturer & 166 & 50 & 45 & 90 \\
Planning Staff & 7 & 7 & 6 & 86 \\
Student & 4170 & 480 & 323 & 67 \\
Total & 4365 & 559 & 393 & 70 \\
\hline
\end{tabular}




\subsection{Performance appraisal process by planning department}

Information from the Planning Department revealed that performance appraisal is an activity undertaken semester to determine the extent to which lecturers perform their teaching duties effectively. An appraisal form is given to students two weeks to end of the semester to appraise lecturers on the courses taught for the semester. With the data collected from students the Planning Department analyses the data using the graphic rating scale method and the weighted average method. The feedback is given to lecturers and Management.

It is used to reward lecturers and for decision making by Management. The appraisal has helped in identifying lecturers who perform efficiently as well as those who need to improve on their performance.

The trend analysis as indicated in Fig. 2 indicates the teaching performance in the Appraisal report conducted from 2007-2010 by the Planning Department. This indicates that Lecturer's performance has been increasing gradually over the years, (3.98 - 4.37) from 2007 to 2010.

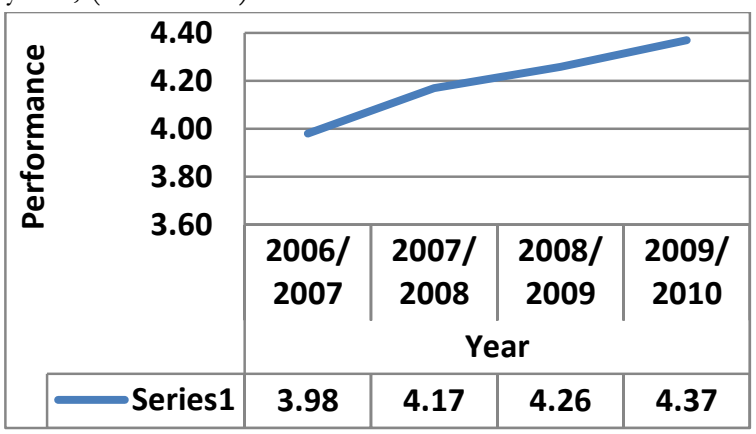

Fig. 2: Trend analysis of performance appraisal of lecturers (2006-2010)

4.2 Meaning, importance, strengths and weakness of performance appraisal by respondents

The appraisal process from the respondents' perspective examined the meaning, importance, strengths and weakness.

Table 2

Respondents' understanding of performance appraisal

Understanding of Performance Appraisal

Frequency

Percentage $(\%)$

A formal and structured system by which management measures, evaluates and assesses an employee's job.

In Table 2, $29.79 \%$ of respondents believed that performance appraisal is a formal and structured system by which management measures, evaluates and assesses an employee's job-related attributes, behaviour and outcomes was the highest among the respondents.
The main importance of performance appraisal centered on the principles and practices of performance appraisal being institutionalized which recorded the highest percentage of $81 \%$ in fig. 3 .

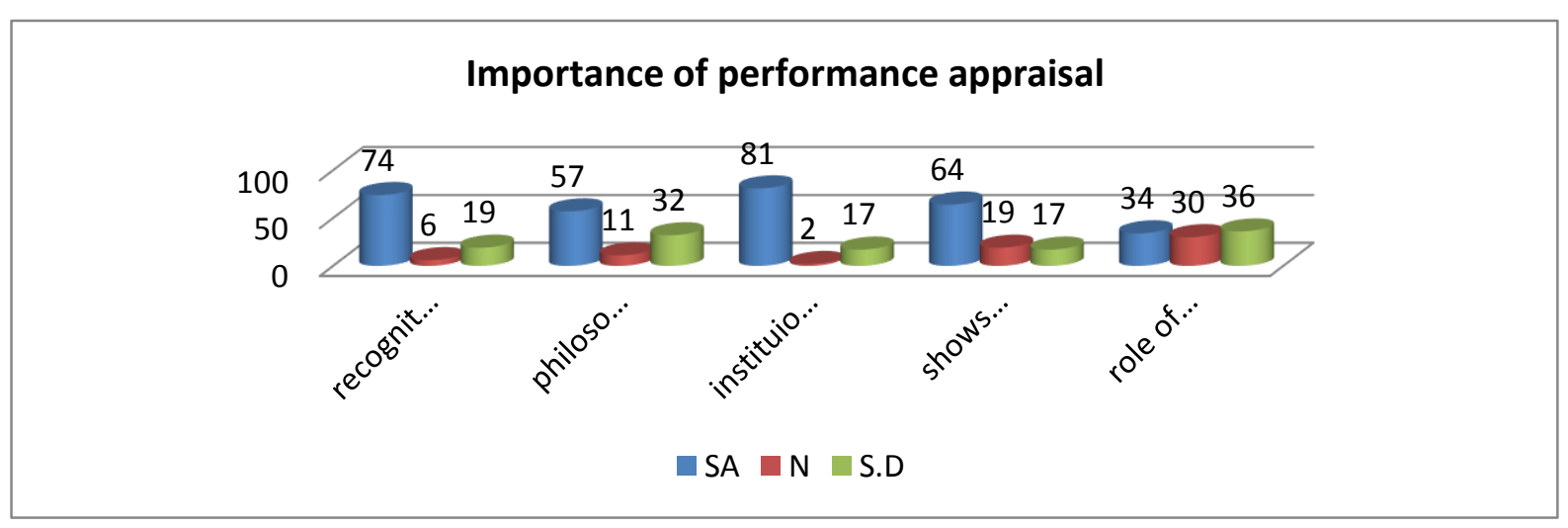

Fig. 3: A bar chart showing responses on importance of performance appraisal 
In Table 3, the strengths highlighted on the policies of performance appraisal being known to all staff with the highest factor loading of 0.630 . Weaknesses dwelt on poor understanding of performance appraisal among staff and students which recorded $84 \%$ in table 4 .

Table 3

Factor analysis on strengths of performance appraisal

\begin{tabular}{ll}
\hline Factor Matrix & \\
\hline & Factor \\
Variables & 1 \\
Teaching staff conform to specific standards with regards to their duties of teaching and & 0.564992 \\
administrative roles by laid down policies & 0.630402 \\
Policies on PA should be known to all lecturers & 0.590127 \\
Top management, middle management and staff support the system & 0.522136 \\
\hline Standardized procedures/processes are followed by Planning Department.
\end{tabular}

Table 4

Weakness of performance appraisal

\begin{tabular}{llll}
\hline Weaknesses of Performance Appraisal & $\begin{array}{l}\text { Strongly Agree } \\
\text { Agree }(\%)\end{array}$ & Neutral (\%) & $\begin{array}{l}\text { Disagree/ } \\
\text { Strongly Disagree } \\
(\%)\end{array}$ \\
\hline $\begin{array}{l}\text { Poor understanding of performance appraisal by staff } \\
\text { and students may render the system ineffective }\end{array}$ & 84 & 1 & 14 \\
\begin{tabular}{l} 
Lecturers perceive performance appraisal as a threat \\
\hline
\end{tabular}
\end{tabular}

\section{Compliance of lecturers}

Students (appraisers) appraise Lecturers on courses taught in the semester. Respondents commented on the four broad performance indicators used to appraise lecturers with $85 \%$ concluding that lecturers provided Course structure , $65 \%$ agreed to ineffective mode of delivery , $60 \%$ supported an impressive lecturer's availability and $70 \%$ agreed on pedagogy. However, $89 \%$ of respondents do not receive feedback and $82 \%$ agreed that management do not adhere to their concerns raised through performance appraisal. Lecturers (appraisees) receive feedback from the appraisal, with $60 \%$ of respondents viewing performance appraisal as a threat. The Planning Department implements the appraisal for students and staff, prepares appraisal document and gives feedback to lecturers and Management. Management supports the appraisal by approving and providing the needed resources to the Planning Department. However, no action is taken by Management for lecturers who consistently perform poorly. It is important to note that the roles played by the stakeholders are ineffective and a good strategy requires proper coordination and education for management, staff and students of the polytechnic. 
Table 5

Students' opinion on effects of performance appraisal on lecturer's productivity

\begin{tabular}{|c|c|c|c|c|}
\hline & \multicolumn{4}{|l|}{ Response } \\
\hline & \multicolumn{2}{|l|}{ Yes } & \multicolumn{2}{|l|}{ No } \\
\hline & Frequency & Percent & Frequency & Percent \\
\hline $\begin{array}{l}\text { Is performance appraisal enhancing } \\
\text { teaching and } \\
\text { learning? }\end{array}$ & 145 & 45 & 178 & 55 \\
\hline $\begin{array}{l}\text { Does management adhere to your } \\
\text { concerns raised through performance } \\
\text { appraisal? }\end{array}$ & 59 & 18 & 260 & 82 \\
\hline $\begin{array}{l}\text { Do you receive feedback from the } \\
\text { appraisal exercise }\end{array}$ & 34 & 11 & 289 & 89 \\
\hline
\end{tabular}

\section{Effects of performance appraisal on lecturer productivity}

Table 6

Staff opinion on effects of performance appraisal on lecturer's productivity

\begin{tabular}{lllll}
\multicolumn{1}{c}{ Variables } & $\begin{array}{l}\text { Response } \\
\text { Yes } \\
\text { Frequency }\end{array}$ & Percent & Frequency & Percent \\
\hline $\begin{array}{l}\text { Is performance appraisal enhancing } \\
\text { teaching and } \\
\text { learning? }\end{array}$ & 40 & 58 & 30 & 42 \\
\hline
\end{tabular}

Opinions of students from table 5 showed a negative effect of performance appraisal on lecturer productivity at the Polytechnic, with $45 \%$ of students agreeing to this assertion while $55 \%$ were of the counter view.

In table $6,58 \%$ of staff agreed that there is a positive effect of performance appraisal on lecturer productivity as against $42 \%$. This implies that a greater number of students do not realize the effect of performance appraisal on lecturer's productivity.

\section{Discussion}

Analysis so far has shown that performance appraisal in Koforidua Polytechnic has not had much effect on lecturers' productivity as concerns of students in the appraisal exercise have been given little attention by all stakeholders. Victimization of students, little recognition of the importance of the conduct of appraisal and poor feedback to the appraisal process have limited the impact on productivity. Evidence from our finding indicate that $60 \%$ of lecturers see performance appraisal as a threat and as such use the outcome of the exercise to victimize students instead of improving on their weak areas. The poor feedback is given to students as findings indicate that $82 \%$ of students are of the view that management do not adhere to their concerns raised through performance appraisal since the same challenges keep on reoccurring. The opinion of students currently on the effects of performance appraisal enhancing lecturers' productivity is in contrast with the appraisal reports from the Planning Department from 2006-2010, where performance of lecturers has been increasing. It was realized from the findings that the productivity in relation to the lecturer's bearing in class was low among the number of respondents. Management's inaction and poor feedback to students on the appraisal has contributed to the weakness of the system where students become reluctant in rating the lecturers. It is prudent from the findings that all stakeholders become committed to the appraisal system in place so that it yields the desired productivity thereby ensuring confidence and consistency in the outcome. 


\section{Conclusion}

The appraisal process depicted the importance, strengths and weakness of the system which required continuous improvement and review to enhance productivity. It was also revealed that a greater number of respondents agreed to an effective course presentation but had counterviews on the mode of delivery. Furthermore, there were two opposing views on the opinion of staff as against that of students on performance appraisal enhancing lecturer's productivity. Majority of the students agreed that performance appraisal does not have much effect on teaching and learning while staff thinks otherwise. Feedback to students and concerns raised through performance appraisal are not given much attention by Management.

Institutionalization of the practices and principles of performance appraisal is recognized as key to enhancing productivity of staff of the Polytechnic. It is fundamental, that continuous education, workshops and training be given to all stakeholders and a performance appraisal handbook be developed by the Polytechnic. For stakeholders to be effective, there must be proper coordination and this therefore calls for an Appraisal Review Committee for a more transparent, fair and objective system. Benchmark practices that pertain in other sister Polytechnics and Universities should be adopted. Motivational packages should be awarded to deserving staff while consistently poor performing lecturers need disciplinary action. From these two opposing views of performance appraisal enhancing productivity, it is recommended that Management bridges the gap between the perceptions and the realities provided by the results of the appraisal to enhance consistency in the assessment by students that will help track performance of lecturers and improve productivity.

\section{References}

Evres, P.,Longnecker, C. and Gioia, D., (2002).Problems to Avoid During Performance Appraisal,Air Conditioning, Heating \& Refrigeration News, Issue 216, No. 16,pp. 24-26.

Ivancewich, J.M., (2004).Human Resources Management ( $9^{\text {th }}$ Edn). New York:McGraw Hill.

Keirstead, J.,(2010).Management of Environmental Quality.Loughborough University, Vol. 21, Issue 1,pp. 6-19.

Kotler, P. and Keller K., (2006) Marketing Management (12 $\left.{ }^{\text {th }} \mathrm{Edn}\right)$. UK: Prentice Hall.
Kusure, L.P., Mutanda, L.,Mawere, D. and Dhliwayo, L., (2006).Factors Influencing Research Productivity among Lectures in Teachers' Colleges in Zimbabwe, Southern Africa Journal of Education, Science and Technology, Vol.., pp..

Mathis, L. and Jackson, J. H., (2004).Human Resource Management $\left(10^{\text {th }} \mathrm{Edn}\right)$.International Students Edition. USA: South Western, Thomson Learning.

Ologunde, A.O., Asaolu, T.O. and Eluilade, D.O., (2006).Motivation and Labour Turnover

among University Teachers in Southwest Nigeria, European Journal of Social Sciences, Vol. 2, No. 1,pp. $1-14$.

Reingold, J. and Stepanek, M., (2000).Why Production Revolution Will Spread, Business Week, Feb. 14 pp. 112-118.

Shresta, S., (2005). "Productivity Measurement in Educational Sector with Special Reference to TU'.Paper presented at the NQPCN Monthly Meeting. Retrieved on 11 $11^{\text {th }}$ June, 2014[online] at:http://nqpcn.org.np/wpcontent/uploads/2012 /07/nqpen-paper-sunity.pdf.

Snell, S. and Bohalander, G., (2007).Human Resource Management. International Students Edition. USA: Thomson Higher Education.

Terry, G. and Franklin, S.G., (2003). Principles of Management ( $\left.8^{\text {th }} \mathrm{Edn}\right) . \quad$ Delhi India: AITBS Publishers, pp.386. 